\title{
土塗り壁のせん断抵抗機構およびせん断耐力の評価法に関する実験的研究 AN EXPERIMENTAL STUDY ON SHEAR RESISTING MECHANISM AND SHEAR STRENGTH EVALUATION METHOD OF MUD-PLASTERED WALLS
}

\author{
中尾方 人*, 一文字 里紗**, 山崎 裕***, 石 橋 庸 子**** \\ Masato NAKAO, Risa ICHIMONJI, Yutaka YAMAZAKI \\ and Yoko ISHIBASHI
}

\begin{abstract}
This study is to clarify the shear resisting mechanism and establish a shear strength evaluation method for mud-plastered walls through shear loading tests of mud-plastered wall specimens. Since two failure modes were observed throughout the tests, two shear resisting mechanisms were established. Therefore, the minimum value among the strengths corresponding to these two mechanisms was taken as the shear strength of the mud-plastered wall. Taking into account the compressive and tensile strength of mud, the evaluation method based on the shear resisting mechanisms for mud-plastered walls provided a good estimation of the shear strength.
\end{abstract}

Keywords : Mud-plastered wall, Shear resisting mechanism, Shear strength, Material testing 土塗り壁, せん断抵抗機構, せん断耐力, 材料試験

\section{1.はじめに}

土塗り壁は，古くから日本の住宅の壁として用いられてきたが， 特に都市部においては，年々その数は減少している。このことは， 施工に要する日数が長いことやそれに伴うコストの增加, 住宅建材 の多様化など様々な要因があるが，そのうちの一つとして，耐震性 能が低いと思われていることもある。

土塗り壁の耐震性能を検証するための静的なせん断加力実験は,

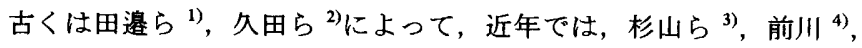
鈴木ら ${ }^{5}$ ，大橋ら のよって行われ，特定の仕様の土塗り壁につい ては，0.5 以上の壁倍率を与えることが可能になった。また，村上 ら `は, 種々の仕様の試験体による実験結果から土塗り壁の耐荷機 構を解明し, 要素試験によりその荷重一変形関倸を推定する手法を 提案している。

それでもなお，構法が多種多様である土塗り壁の耐震性能を容易 に評価することは難しいが，ある程度の耐震性能を有していること は一般的に知られるようになりつつある。

筆者らも，土塗り壁の耐震性能とそれに大きな影響を与えるであ ろうと思われる壁土の力学的特性との関保に着目し，実験的な検討

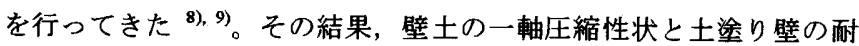
力性状との関保はある程度把握できたが, 耐震性能を評価する方法
を示すまでには至っていない。

本研究では, 関東地方でみられる棈法の土塗り壁を対象とした試 験体の静的せん断加力試験を行い，そのせん断抵抗機構を明らかに するとともに, 壁土の材料試験結果から土塗り壁の最大負担せん断 力（せん断耐力）の推定を試みる。

\section{2. 実験計画の策定}

筆者らがこれまでに行った実験研究 ${ }^{8)}$ ) 9)では，図1に示すような 土塗り壁の試験体を用いて検討を行ってきた。3 本の横貫は通し貫 とし, 楔で留めている。壁長が $1820 \mathrm{~mm}$ の場合には, 両側柱の中央 に縦貫も配している。間渡し竹には直径 $12 \mathrm{~mm}$ 程度の丸竹を用いて おり，その端部は軸組に設けた穴に $10 \mathrm{~mm}$ 程度差し込み，貫に釬で 留められている。小舞竹は幅が $20 \mathrm{~mm}$ 程度の割竹であり, 間渡し竹 にわら縄で結わえられ，その端部は軸組の内側の面からは $10 \mathrm{~mm}$ 程 度離れている。この試験体では，3 本の横貫のうち，地貫と頭貫の 位置は実際の建物での位置とは異なるが，これは，貫で区切られた 壁土の各部分の寸法を同程度として，各部の破壊性状を比較するた めと，仕口に取り付けているホールダウン金物との干渉を避けるた めである。壁土の材料となる土は荒木田土である。水合わせ後，夏 期に 3 ケ月程度寝かせたものを荒壁用の壁土として用い，荒壁が乾
* 横浜国立大学大学院工学研究院 助手 · 修士 (工学)

** ナイス侏) 修士 (工学)

(元 横浜国立大学大学院工学府 博士課程前期)

**** 横浜国立大学大学院工学研究院 教授・工博

**** 横浜国立大学大学院工学府 博士課程後期・修上(工学
Research Assoc., Faculty of Engineering, Yokohama National University, M. Eng. Nice Corporation, M. Eng.

Prof., Faculty of Engineering, Yokohama National University, Dr. Eng. Graduate Student, Graduate School of Engineering, Yokohama National University, M. Eng. 
燥してひび割れが十分生じるのを待って, 中付けと中塗りを両面に 行う。中付けは，中塗りに先立って壁面をならす工程であり，中塗 りの前日か直前に行われる。乾燥後は, 中付け層と中塗り層とは完 全に一体化する。中付けと中塗りに用いる壁土は，荒壁用の壁土に 砂を加えたものであり，中塗り仕上げの場合の標準的な壁厚は，50 〜 55mm 程度である。

上記のような構法の土塗り壁を対象とし, 高さ $(2730 \mathrm{~mm}$ と $1820 \mathrm{~mm})$, 壁長 $(1820 \mathrm{~mm}$ と $910 \mathrm{~mm})$, 仕上げの程度（軸組のみ, 荒壁塗りまで, 中塗り仕上げ）をパラメータとして, 静的せん断加 力試験を行った結果からは，土塗り壁の耐力および変形性状につい て，主に以下のことが明らかになっている ${ }^{8), 99}$ 。

・頂部に水平に載荷されたせん断力の大部分は, 中付けおよび中塗 り層で負担されている。また，中付け土や中塗り土の圧縮応力度 一変位関係と，土叙り壁の中付けおよび中㙦り層が負担する平均 負担せん断応力度一層間変形角関保とは相関がある。

・壁長が $1820 \mathrm{~mm}$ の試験体では，壁土の中段部にせん断ひび割れが 生じて破壊したのに対し，壁長が $910 \mathrm{~mm}$ の場合にはせん断ひび 割れはみられず，壁土全体が軸組内で回転し，貫上の中付けおよ び中塗り層が面外一浮き上がる様子が観察された。このとき，中 付けおよび中塗り層が負担するせん断力は，壁長が $1820 \mathrm{~mm}$ の場 合に比べて約 1/4であった。

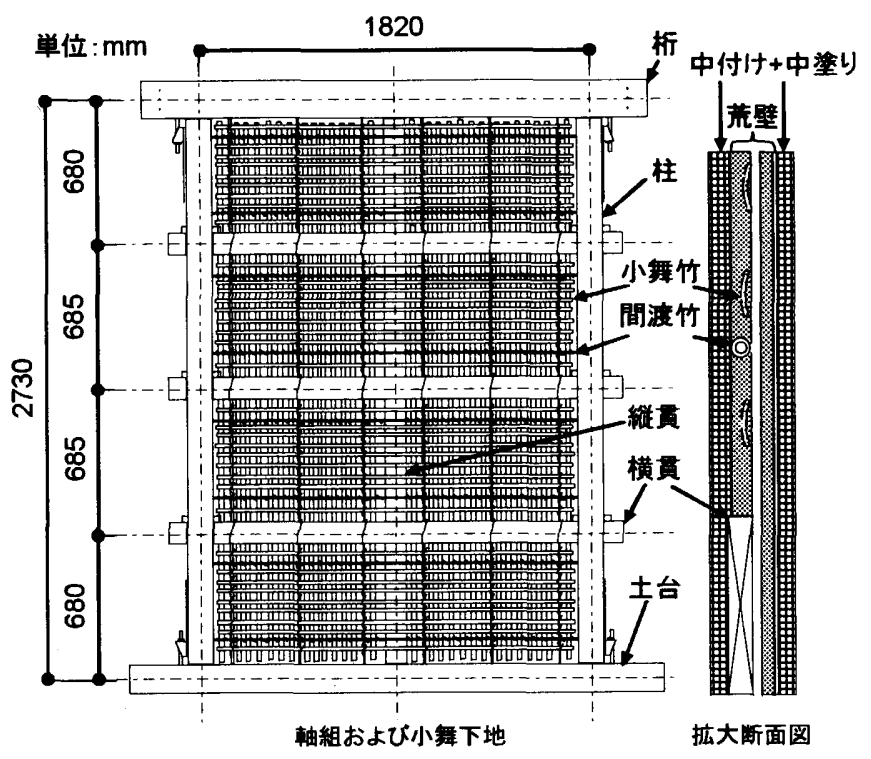

図 1 本研究で対象とする土準り壁

表 1 土塗り壁試験体の一覧

\begin{tabular}{|c|c|c|c|c|c|c|c|}
\hline \multirow{3}{*}{$\begin{array}{l}\text { 試験 } \\
\text { 体名 }\end{array}$} & \multirow{3}{*}{$\begin{array}{l}\text { 壁長 } \\
\text { (mm) }\end{array}$} & \multirow{3}{*}{$\begin{array}{r}\text { 澼 } \\
\text { 荒壁 }\end{array}$} & \multirow{2}{*}{\multicolumn{2}{|c|}{ 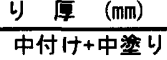 }} & \multirow{2}{*}{\multicolumn{2}{|c|}{ 四の本数 }} & \multirow{3}{*}{ 特 敨 } \\
\hline & & & & & & & \\
\hline & & & 橫貫側 & 緛貫側 & 横曼 & 暶貫 & \\
\hline D1 & \multirow{6}{*}{1820} & \multirow{6}{*}{30} & 0 & 0 & \multirow{2}{*}{3} & \multirow{6}{*}{1} & 荒壁喔りまで \\
\hline D2 & & & \multirow{2}{*}{15} & \multirow{2}{*}{15} & & & \multirow{2}{*}{ 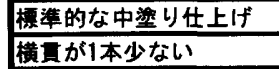 } \\
\hline$\overline{\mathrm{D} 2 \mathrm{~N}}$ & & & & & 2 & & \\
\hline D2T & & & 25 & 25 & \multirow{3}{*}{3} & & 中付け+中埿り層が厚い \\
\hline D2L & & & 15 & 0 & & & 横塞側のみ中筀り仕上げ \\
\hline D2V & & & 0 & 15 & & & 紽貫側のみ中淮り甘上げ \\
\hline E1 & \multirow{4}{*}{910} & \multirow{4}{*}{30} & 0 & 0 & \multirow{2}{*}{3} & \multirow{4}{*}{0} & 荒壁塱りまで \\
\hline E2 & & & 15 & 15 & & & 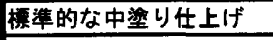 \\
\hline E2N & & & & & 4 & & 横悬が1本多い \\
\hline$\overline{\text { E2T }}$ & & & 25 & 25 & 3 & & 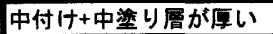 \\
\hline
\end{tabular}

この結果からは, 土塗り壁のせん断耐力は, 中付けおよび中塗り 層の破壊形式に深く関係していると考えられるため，本研究での試 験体構成は, 中付けおよび中塗り層の厚さや壁長, 横貫の本数をパ ラメータとして表 1 および図 2 のように計画した。ここで，荒壁層 で負担されるせん断力は，中付けおよび中塗り層がある場合とない 場合とでは異なると考えられるが，中付けおよび中塗り層で負担さ れるせん断力に比心゙て小さいと予想される。ゆえに，壁土により負 担されるせん断力は，全て中付けおよび中塗り層で負担されると仮 定している。横貫の本数を変化させるにあたり，その本数が多いほ ど壁土の回転が抑えられると考え, 壁長が $1820 \mathrm{~mm}$ の試験体では横 貫を 2 本に, $910 \mathrm{~mm}$ の陚験体では 4 本として，上記のような害験結 果とは異なる破壊形式となることを意図した。即ち、D2N 試験体で は, 壁土が軸組内で回転してせん断ひび割れが生じない破壊形式, E2N 試験体では，壁土にせん断ひび割れが生じて破壊することを想 定している。また，D2L と D2V 試験体では，表面（横貫側）と裹 面（維貫側）における，中付けおよび中塗り層の負担せん断力の比 較を目的としている。

本研究での試験体の製作も前述した棬法で行った。塗り厚につい ては，実測值を図 3 に示したが，概ね目標の塗り厚に近く施工でき ている。なお，D2Tおよび E2T 試験体では，中塗りを2回行って概 ね目標の塗り厚以上となった。

土塗り壁の静的せん断加力試験の方法は，ホールダウン金物 (S-HD15)による柱脚固定式とし，図4 に示す履歴で加力を行った。 因 5 は変位等の計測位置である。壁土の挙動は, 壁面全体にマーカ 一を取り付けて写真から追えるようにした。また，軸組の変形は， 変位計により計測した。

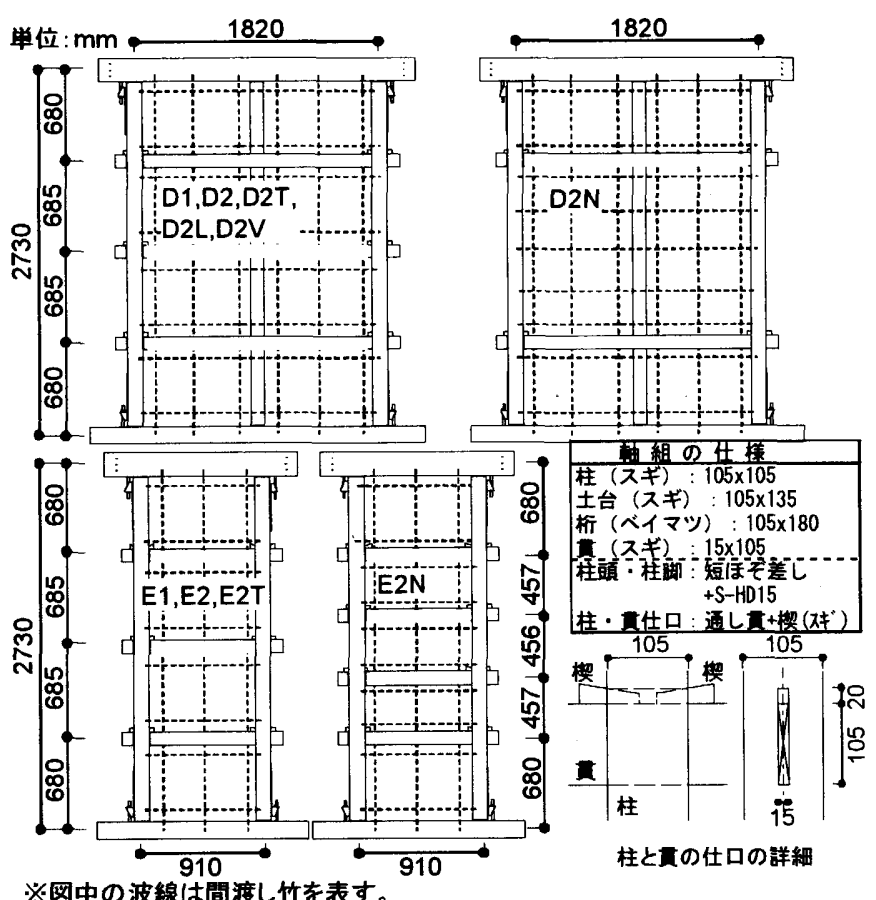

図 2 試験体の軸組および間渡し竹 


\section{3. 実験結果および考察}

\section{1. 耐カおよひ破壊性状}

各試験体の荷重一変形関係の包絡線を図 6 に示す。

荒壁のみの試験体（以下, 荒壁試験体々略す） D1, E1 では, 加 力終了まで負担せん断力が增加し続けた。これは，文献 8)に示した 結果から判断すると，荒壁土により負担されているせん断力はわず かで，ホールダウン金物で仕口を補強された軸組による負担力が， 層間変形角に比例して増加し続けるためであると考えられる。

壁長が $1820 \mathrm{~mm}$ の中塗り仕上げの試験体（以下，中塗り試験体之 略す） D2，D2N，D2T，D2L および D2Vでは，まず，壁土の隅角部 で横架材と接する部分が圧壊して壁土全体が軸組内で回転した。そ の後, D2T 以外の各試験体では 1/150 rad で, D2T 試験体では 1/75 rad でせん断ひび割れが確認され，D2L と D2V 試験体では 1/100radで,
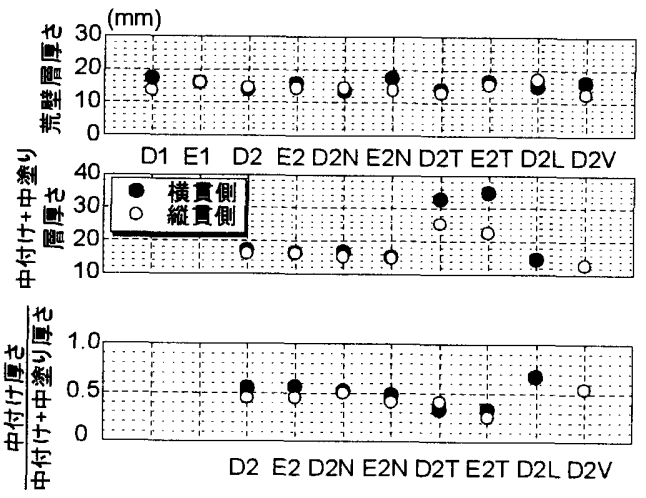

図 3 各層の塗り厚の実測値

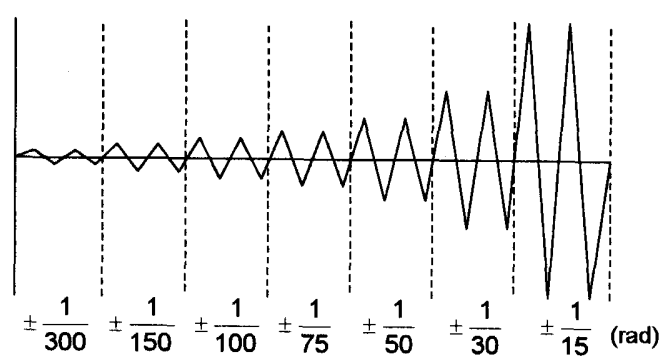

図 4 加力履歴
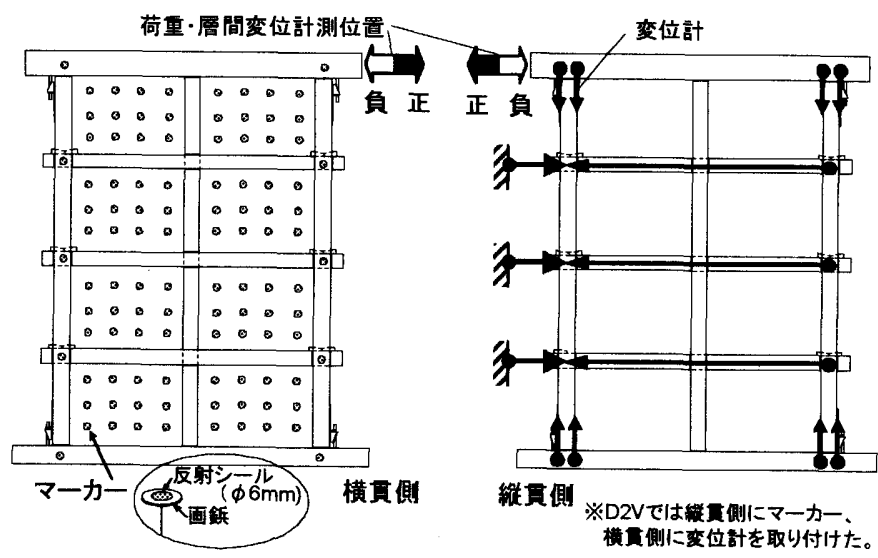

図 5 变位等㖕測位置
その他の試験体では $1 / 50 \mathrm{rad}$ で負担せん断力が最大となった。最大 負担せん断力時のひび割れの発生状況を図 7 に示寸。D2,D2N, D2L, $\mathrm{D} 2 \mathrm{~V}$ の各試験体では，貫上のひび割れに沿ったスリップ状の圧壊 $\left(\right.$ スリップ破壊 ${ }^{10)}$ ) が生じており，これは，鉄筋コンクリート造耐 震壁でみられる破壊性状に似たものである。D2T 試験体では $1 / 50 \mathrm{rad}$ で壁土が面外に浮き上がり，1/30 $\mathrm{rad}$ 時には剥がれ落ちそうになった ため，その時点で加力を中止した。壁長が $1820 \mathrm{~mm}$ のいずれの試験 体でも，1/100 rad 前後から柱の上下端部付近に接する壁士にも圧壊 がみられ，壁土は柱から水平力を受けていると考えられる。

壁長が $910 \mathrm{~mm}$ の中叙り試験体 E2, E2N および E2Tでは, 軸組の せん断変形が進むにつれて，壁土の隅角部で横架材に接する部分の 圧壊が顕著にみられた。そして，壁長が $1820 \mathrm{~mm}$ の中塗り試験体よ りも壁土が軸組内で大きく回転し，剛性が低下した後も緩やかに負 担せん断力が上昇しつづけた。1/50 rad 前後からは, 隅角部掞よび軸 組と貫の仕口付近の壁土が面外に浮き上がり, その後, 壁土全体が 面外に浮き上がる様子が確認された。E2N 試験体では，1/30 rad 時に
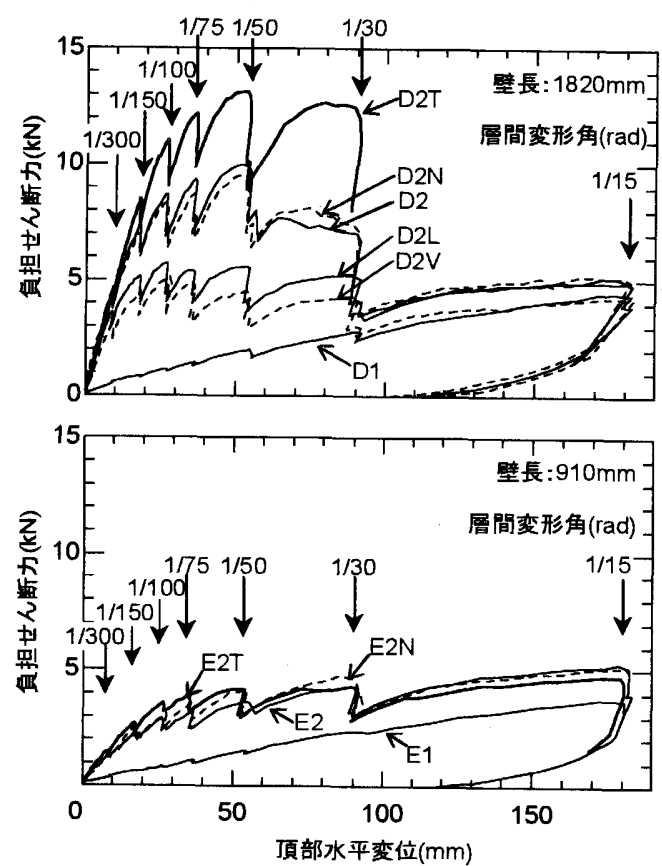

図 6 荷重一変形関係
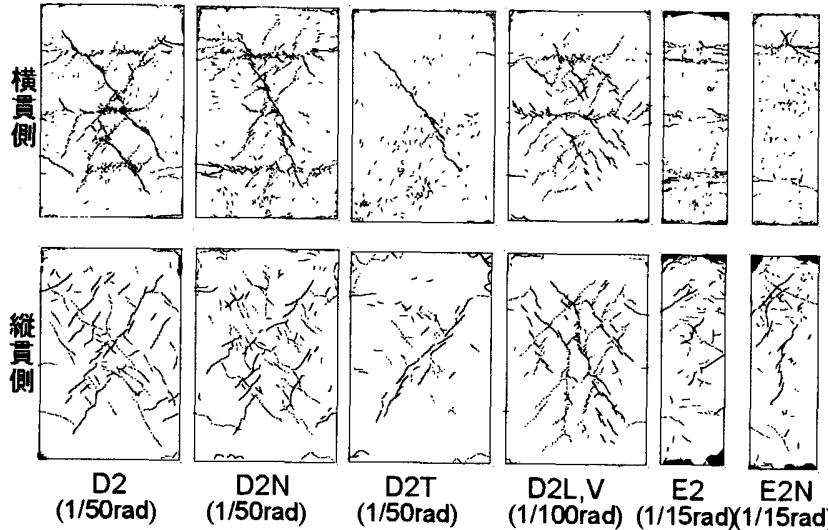

図 7 ひび割れの発生状況 
せん断ひび割れが生じたが，E2 と E2T 試験体では，加力終了まで にせん断ひび割れはみられなかった。E2 および E2N 試験体では， 貫の雨端部付近で壁土が面外に浮き上がったことによると思われる 面外曲げひび割れがみられたが，E2T 試験体では隅角部以外に目立 った損傷はなく，1/15rad 時に壁土全体が一体となって剥がれ落ちた。 本実験における壁土の破壊形式は，概放 2 種類に分類できるが， それぞれの破壊形式を代表して，D2 および E2 試験体の破壊過程の 模式図を図 8 に示した。

\section{2 壁土の力学的特性}

壁土の力学的特性を把握するための圧縮試験および引張試験は, 土鉒り壁のせん断加力試験を行った約 2 ケ月間で 2 回実施した。供 試体の型枠は，内法寸法が直径 $50 \mathrm{~mm}$ で高さ $100 \mathrm{~mm}$ の円筒形であ り，5体を 1 セットとした。圧縮および引張力は, 供試体の材軸方 向に載荷し (付録参照), 応力度の算出に用いる断面積は, 試験の前 日に測定した直径から求めた。試験結果を図 9 に示す。

2 回の材料試験の間は約 1 ケ月あったが，盖生期間の差による影 響はみられなかった。荒壁土の供試体には，壁と同様に多くの乾燥 ひび割れがみられ，図10に示したように，中付け土や中塗り土に比

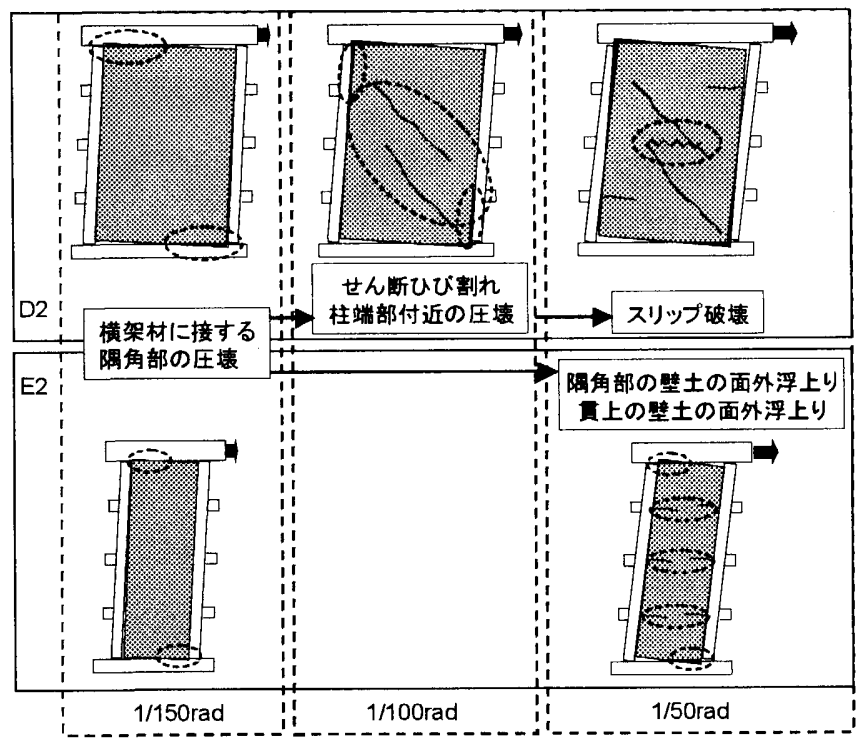

図 8 破棲過程の模式図

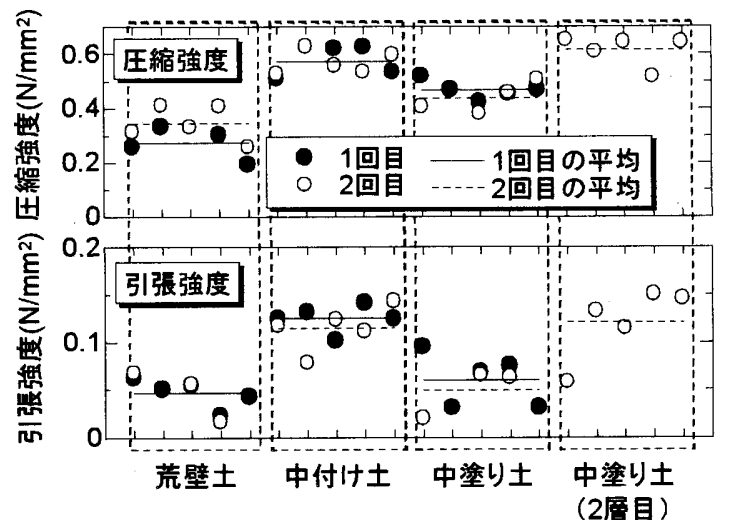

図 9 壁土の材料強度
ぶて粑性，強度ともに低い。中付け土と中塗り土とでは，圧縮応力 度と変位との関係は似ており，いずれも圧縮変位が約 $2 \mathrm{~mm}$ で最大 忘力度となる。このように，中付け土と中塗り土とは力学的にほぼ 同様の性状であり，土塗り壁のせん断加力試験でも両者は一体とし て挙動していたため、これ以降, 中塗り試験体に扔ける中塗り層を 指す場合には中付け層も含むものとする。

\section{3 各部の変形性状}

図 11 は, 中塗り試験体における両側柱の各点の水平方向の変位を, 荒壁試験体の同じ位置における変位との差で表したものである。軸 組の変形に伴って，両側の柱が外側に押し出されるように変形して いることが分かる。なお，荒壁試験体における両側柱では，大変形 域においてホールダウン金物による拘束力の影響がみられたが，ほ ぼ直線とみなせる結果であった。

図 12 に壁土の土台に対する回転角を示す。これは，壁土の表面に 取り付けたマーカーのうち，最も外側に位置する左右 2 列のマーカ 一について，それぞれの列での土台に対する鉛直方向の移動量の平 均值を求め, その差を 2 列の間隔で除すことで求めた。

荒壁試験体 D1，E1 では，荒壁土が軸組とともにせん断変形して いるため，回転量は少ない。一方，中塗り試験体では，隅角部で横 架材と接する部分が压壊することで壁土が回転しており，壁長が $910 \mathrm{~mm}$ の E2, E2N，E2T の各試験体では, 層間変形角と同程度の回 転角である。壁長が $1820 \mathrm{~mm}$ の各試験体では，910mmの試験体より も回転角は小さいが，これはせん断ひび割れや，柱の上下端部付近

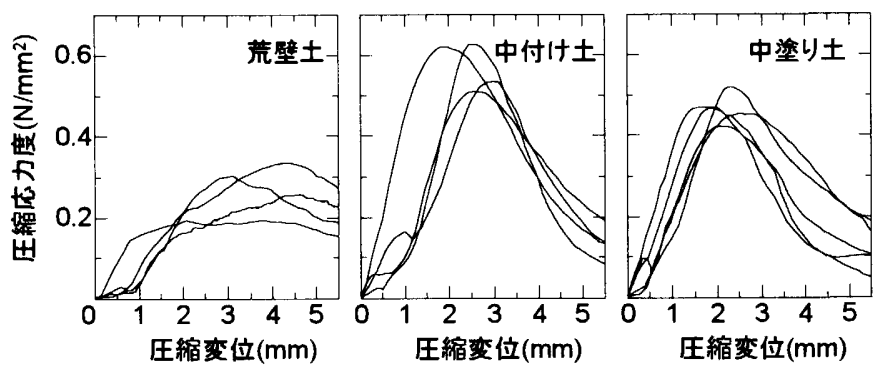

图 10 各壁土の圧縮応力度一变位関係

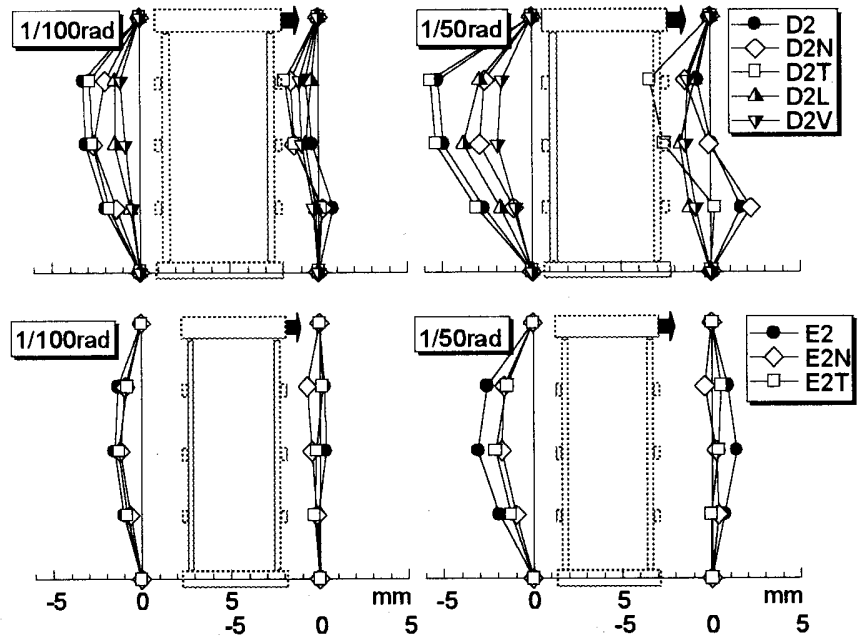

図 11 中塗り試験体の両側柱の水平方向の变形 
に接する壁土に圧壊が生じていたためであると考えられる。

\section{4 壁土の破壊形式およびせん断耐カに関する考察}

ここでは，土塗り壁の破壊形式およびせん断耐力について，中塗 り層の最大負担せん断力（以下，壁土の破壊形式を問わず「中塗り 層のせん断耐力」と呼ぶ）の観点から考察する。ここで，中塗り層 の負担せん断力とは，同一の層間変形角において，中塗り試験体の 負担せん断力から，荒壁試験体の負担せん断力を差し引いたものと する。前述のように，荒壁試験体の負担せん断力のうち軸組が負担 する割合は, 変形に伴って增加するため, 大変形域では，大部分の せん断力は軸組により負担される。土塗り壁のせん断耐力について 考える場合，この軸組による負担せん断力を差し引かない限り，壁 土自体が最大の強度を発揮する点，および，それに対応した壁土の 破壊形式が特定できない。ここでは，便宜的に中塗り層の負担せん 断力という概念を導入したが,壁土が負担するせん断力の算定には， 軸組の応力分布等について詳細な検討が必要である。图 13 に中塗り 試験体における中塗り層の負担せん断力の推移を示し，以下に考察 を加える。

\section{（a）壁土の破壊形式について}

壁長が $1820 \mathrm{~mm}$ の中塗り試験体のうち，D2L と D2V 試験体では 1/100 rad で，D2，D2N および D2T 試験体では 1/50 rad で中塗り層の 負担せん断力が最大となっている。一方，壁長が $910 \mathrm{~mm}$ の中塗り 試験体においては，E2T 試験体では 1/100rad で，E2 と E2N 試験体 では 1/50radで中塗り層の負担せん断力が最大である。

各試験体について，中叙り層の負担せん断力が最大となった層間 変形角の前後での破壊性状を考慮すると, 各試験体の破壊形式は， D2，D2N，D2L，D2V 試験体はスリップ破壊，D2T，E2，E2N，E2T 試験体は壁土の面外への浮き上がりであったと考えられる。

\section{(b) 中塗り層のせん断耐カについて}

中塗り層が横貫側のみにある D2L 試験体と繸貫側のみにある $\mathrm{D} 2 \mathrm{~V}$ 試験体とはほぼ同じ耐力性状であり，両者の中塗り層のせん断 耐力は，両側に中塗り層を有する D2 試験体の約 $1 / 2$ である。 D2L, $\mathrm{D} 2 \mathrm{~V}$ および D2 試験体の破壊形式が同じであることも考慮すると， 中塗り層はそのすぐ下の貫や小舞竹の方向によらず，同程度のせん 断力を負担することが分かる。また，中段の横貫がない D2N 試験体 は，D2 試験体とほぼ同じ耐力性状であり，破壊形式も同じであるこ とから，壁長が $1820 \mathrm{~mm}$ の場合には，横貫が中塗り層のせん断耐力

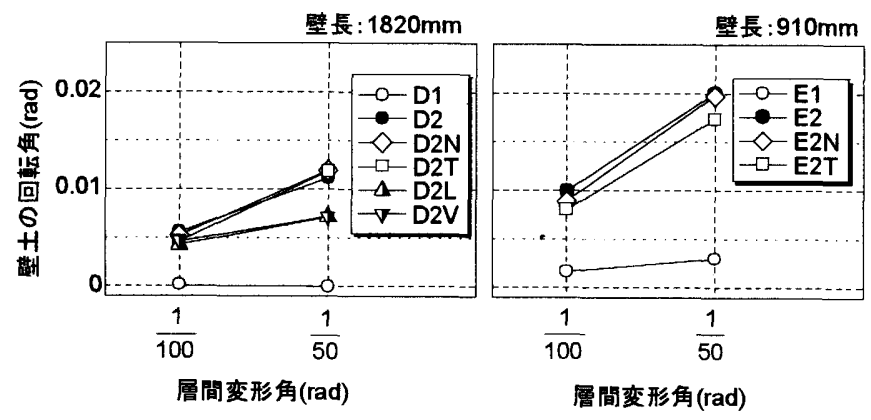

図 12 壁土の回転角と層間变形角の関係
に及ぼす影響は小さいといえる。さらに, 中塗り層の厚さが D2 試 験体の約 1.7 倍である D2T 試験体の中塗り層のせん断耐力は, D2 試験体の約 1.4 倍であり，中塗り層の厚さに比例しているとはいえ ない。これは, 中塗り層の厚さの違いによって, 破壊形式が異なっ たためとみられる。

一方,壁長が $910 \mathrm{~mm}$ である $\mathrm{E} 2$ 試験体の中塗り層のせん断耐力は, D2 試験体の約 1/4 であり，耐力が壁長に比例しないのは破壊形式の 違いのためと考えられる。この E2 試験体と比べて，E2N 試験体の 中㓌り層のせ九断耐力は $20 \%$ 程度高い。これは，図 12 において， E2 と E2N 試験体とでは, 壁土の土台に対する回転角はほぼ同じで あることから, 中段部に追加した貫も, 壁土の回転に対して抵抗力 を発揮していたためと推測される。中叙り層の厚さが $\mathrm{E} 2$ 試験体の 約 1.8 倍である E2T 試験体では, 中塗り層のせん断耐力は E2 試験 体の約 1.4 倍であり，両者の破壊形式は同様であるが，中塗り層の せん断耐力は, 中塗り層の厚さに比例しているとはいえない。これ より，破壊形式が壁土の面外一の浮き上がりである場合には，中塗 り層のみが中塗り層のせん断耐力に影響を及ぼすのではないと考え られる。

\section{4.土塗り壁のせん断抵抗機構}

以上のような実験結果より, 本研究で対象とした構法の土塗り壁 のせん断抵抗機構は, 壁長の違いによらず, 総じて以下の上うに考 えることができる。

軸組の層間変形角が 1/150rad 付近までは，軸組のせん断変形に伴 って, 図 14 のように, 㴊性の高い中塗り層の隅角部に水平力と鉛直 力の合力が対角線方向に作用寸る。この水平力の偶力モーメントと 鈶直力の偶力モーメントとは釣り合うので，壁土の綎横比を考慮す ると, 鉛直力の方が水平力より大きくなる。そのため, 横架材と接
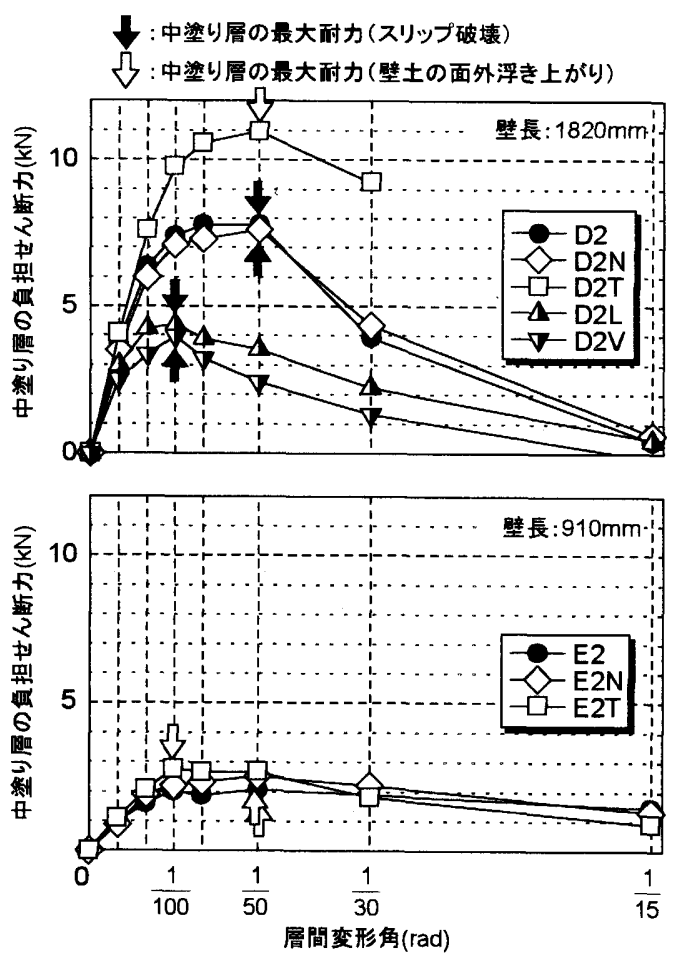

図 13 中塗り詹の負担せん断力の推移 
する部分の壁土が先に圧壊し, 壁土が軸組内で回転する。このとき， 貫は㴊性の低い荒壁層内にあるため，壁土の回転に対する抵抗力は ほとんどないと思われる。

さらに軸組のせん断変形が進み，中塗り層が負担するせん断力が ある程度以上になったときには，せん断ひび割れが生じる。図 15 は，中叙り層の平均負担せん断応力度の推移を示したものである。 これは，中塗り層の負担せん断力を，中付けおよび中塗り層の厚さ と両側柱の内法長さで除して求めた。これによると, D2, D2N, D2L, $\mathrm{D} 2 \mathrm{~V}$ の各試験体では, 1/300 rad から 1/150rad の間に，D2T 試験体で は, 1/100 radから 1/75 rad の間にせん断ひび割れが生じていることか ら，中叙り層にせん断ひび割れが生じるときの平均負担せん断応力 度は $0.1 \mathrm{~N} / \mathrm{mm}^{2}$ 程度であると考えられる。これは, 中付け土と中塗 り土の引張強度の平均值 $0.098 \mathrm{~N} / \mathrm{mm}^{2}$ と同程度である。また, E2N 試験体の中塗り層の最大負担せん断応力度は, 約 $0.1 \mathrm{~N} / \mathrm{mm}^{2}$ であり， 1/30rad 時にはせん断ひび割れが確認されている。E2 および E2T 試 験体では，中塗り層にせん断ひび割れが生じなかったが，この 2 体 の中叙り層の平均負担せん断応力度は $0.08 \mathrm{~N} / \mathrm{mm}^{2}$ 以下であり，せん 断ひび割れが生じるせん断応力度に達していないことが分かる。こ れは，壁長が $910 \mathrm{~mm}$ の試験体の壁土の縦横比は，壁長が $1820 \mathrm{~mm}$ の場合の約 2 倍であるため, 水平力の偶力モーメントによって発生 する鉛直力がより大きく，隅角部の圧壊が早期に生じて，壁土が大 きく回転したためと考えられる。

中塗り層にせん断ひび割れが生じた場合，壁面には圧縮力に抵抗 する機構（圧縮束）が形成されて，スリップ破壊が生じるまでせん 断力が負担される。この破塤形式は，D2，D2N，D2L，D2V 試験体 が該当する。
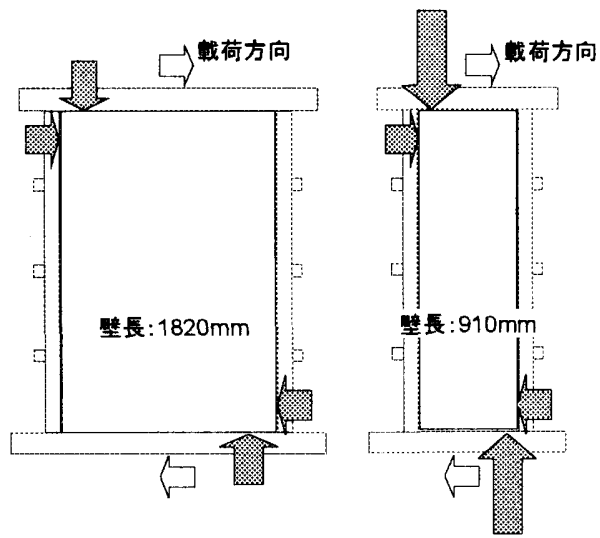

図 14 壁土に作用する水平カと鉛直カとの釣り合い

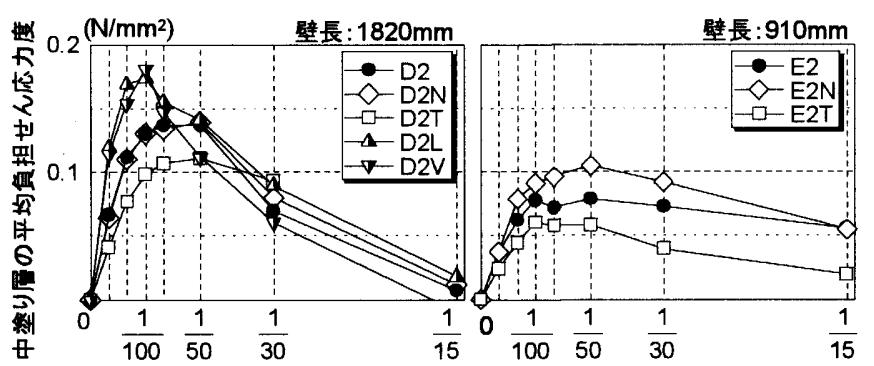

局間变形角(rad)
層間変形角が $1 / 50 \mathrm{rad} に$ 達しても中叙り層にスリップ破壊が生じ ない場合，隅角部ではより広範囲にわたって壁土が圧壊し，壁土が 軸組の中で大きく回転する。このとき，荒壁層が貫付近で圧壊する とともに，隅角部および貫上の中塗り層が面外に浮き上がる。この ような破壊形式の場合の中塗り層のせん断耐力は，中塗り層の隅角 部および貫付近の荒壁層が圧壊するときの中塗り層の負担せん断力 として表せると考えられる。この破壊形式に該当するのは，D2T， E2，E2N，E2T 試験体である。

\section{5.土塗り壁のせん断耐力の定式化}

ここでは，中塗り層のせん断耐力の定式化を試みる。中塗り層の せん断耐力は, 軸組が負担するせん断力を除いた寒質的な土塗り壁 のせん断耐力に近い值であると考えられる。

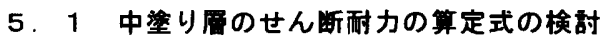

本実験の範用内では, 中塗り層のせん断耐力 $V$ は, 式(1)の上うに 表せる。

$V=\min \left(V_{s}, V_{c o}\right)$

$V:$ 中塗り層のせん断耐力

$V_{s}:$ スリップ破壊が生じるときの中塗り層の負担せん断力

$V_{c o}$ : 隅角部および貫付近の壁土が圧填して, 中塗り層が面 外に浮き上がるときの中塗り層の負担せん断力

ただし，スリップ破塤が生じるためには，せん断ひび割れ後に圧 縮束が形成されることが必要であるため，V、は廿ん断ひび割れが生

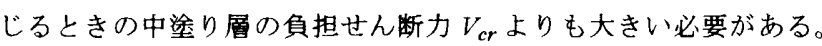

$V_{c r}$ は、ひび割れが生じる前の中塗り層を等方性弾性体とみなし, 一様に純せん断力が作用していると仮定すると，次式で表すことが できる。

$$
\begin{aligned}
& V_{c r}={ }_{n} \sigma_{t} \times t_{n} \times l_{w} \\
& { }_{n} \sigma_{t}: \text { 中塗り土の引張強度 } \\
& t_{n}: \text { 中塗り層の厚さ } \\
& l_{w}: \text { 両側柱の内法長さ }
\end{aligned}
$$

(2)式において，厳密には2 軸応力状態を考慮した引張強度を用い るべきであるが，ここでは，一軸引張試験による引張強度を用いる こととする。

また, $V_{s}$ は, せん断ひび割れ発生後に図 16 のような圧縮束が形 成されると仮定すると，以下のように表すことができる。

$$
\begin{aligned}
& V_{s}={ }_{n} \sigma_{c} \times t_{n} \times l_{w} / 4 \\
& { }_{n} \sigma_{c}: \text { 中塗り土の圧縮強度 }
\end{aligned}
$$

図 16 中の圧縮束が形成される幅 $l_{w} / 2$ は，スリップ破填は貫に沿 って生じていることのほか, せん断ひび割れの角度を 45 度, 中塗り 
層に作用する水平力は柱から伝達されると仮定して決めた。このせ 儿断抵抗機構が成り立つには，鉛直方向の拘束力が存在寸ることが 前提であり，本来はこの力も考慮して圧縮束の幅を決める必要があ る。しかし，D2，D2L，D2Vの各試験体のひび割れの発生状況から， スリップ破壊が生じた長さは $l_{w} / 2$ に近いこと、ひび割れ発生後のせ ん断抵抗機構や式(3)が簡潔に表現できることから，図16のように 水平力の釣り合いのみを考慮した。このせん断抵抗機構によれば, 横貫側と縦貫側の中塗り層のせん断耐力は同等となることが説明で きる。

隅角部および貫付近の壁土が圧壊して，中塗り層が面外に浮き上 がるときの中塗り層の負担せん断力 $V_{c o}$ は, 壁土の圧縮強度, 塗り 厚 (貫の厚さ, 横貫の本数), 両側柱の内法長さの 2 乗に比例すると 仮定し，式(4)で表す。このとき，中塗りおよび荒壁層は一体として 挙動し，中塗り層の隅角部が圧填すると同時に貫周辺の荒壁層も圧 壊すると仮定している。

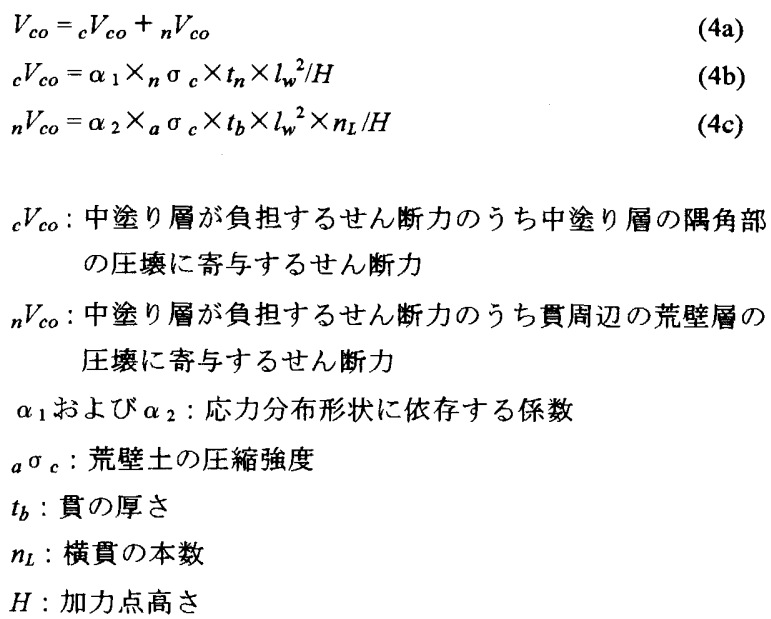

実験結果から推定する横貫 1 本分の ${ }_{n} V_{c o}$ の值は，壁長が $910 \mathrm{~mm}$ の場合, 横貫が 4 本の $\mathrm{E} 2 \mathrm{~N}$ 試験体と, 3 本の $\mathrm{E} 2$ 試験体の中塗り層

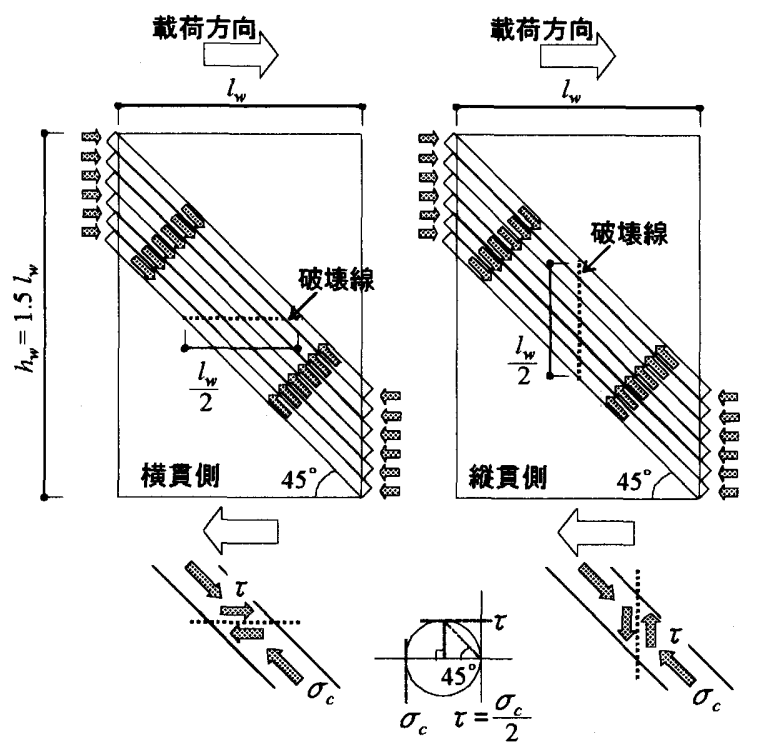

図 16 仮定したせん断ひび割れ後のせん断抵抗機構
のせん断耐力の差 $0.48 \mathrm{kN}$ となる。また, ${ } V_{c o}$ は $\mathrm{E} 2$ 試験体の中塗り 層のせん断耐力 $2.05 \mathrm{kN}$ から 3 本の貫の負担力 $(0.48 \mathrm{kN} \times 3=) 1.44 \mathrm{kN}$ を 差し引いて， $0.61 \mathrm{kN}$ となる。

$\mathrm{E} 2$ 試験体を対象として, ${ }_{n} \sigma_{c}=0.54 \mathrm{~N} / \mathrm{mm}^{2}$ (中付け土と中叙り土 の圧縮強度の平均值), $t_{n}=32 \mathrm{~mm}$ (中付け層と中塗り層の厚さの和), $l_{w}=805 \mathrm{~mm}, H=2730 \mathrm{~mm}$ として,${ }_{c} V_{c o}(=0.61 \mathrm{kN})$ から $\alpha_{1}$ を逆算する と 0.15 となり, 応力分布形状を図 17 (a)のように三角形と仮定した 場合 $\left(\alpha_{1}=1 / 6 \div 0.167\right)$ に近い值となる。同様に ${ }_{n} V_{c o}$ についても， ${ }_{a} \sigma_{c}$ $=0.31 \mathrm{~N} / \mathrm{mm}^{2}, t_{b}=15 \mathrm{~mm}, n_{L}=3$ として ${ }_{n} V_{c o}(=1.44 \mathrm{kN})$ から $\alpha_{2}$ 求め ると 0.43 となり,図 17 (b)のような応力分布の場合 $\left(\alpha_{2}=1 / 6 \doteqdot 0.167\right)$ に比べるとかなり大きな值である。これは，荒壁層が剛性の高い中 塗り層と一体化することで, 実際には材料試験での荒壁土の圧縮強 度より高くなっている可能性があることや，壁土と柱のずれに抵抗 する間渡し竹の負担力，および，貫に間渡し竹を固定している釘の 抵抗力を無視していることが考えられる。文献 7)や11)には，これ らの力も無視できない程度である実験結果が示されている。

\section{2 算定結果と実験值との対応}

表 2 上図 18 に各式による算定結果と実験での中塗り層のせん断耐 力 $V_{\text {exp }}$ との対応を示す。ここで, 壁長が $910 \mathrm{~mm}$ の試験体における $V_{s}$ の算定には, 壁長が $1820 \mathrm{~mm}$ の試験体の破填性状から決めた式(3) をそのまま用いた。このことの妥当性については, 実験で壁長が $910 \mathrm{~mm}$ の試験体にスリップ破壊を生じさせることは難しいために 確認できていないので，壁長が $910 \mathrm{~mm}$ の試験体における $V_{s}$ の値は あくまで参考値として記載した。また, 式(4)における $\alpha_{1}$ と $\alpha_{2}$ は 0.15 と 0.43 を用いているため, $\mathrm{E} 2$ 試験体の $V_{c o}$ と $V_{\text {exp }}$ とは一致している。 いずれの試験体においても， $V_{c r}<V_{s}$ であり，式(1)の適用範囲内に ある。D2N 試験体では, 中叙り層のせん断耐力 $V$ は $V_{c o}$ で評価され ているが，実験での破壊形式はスリップ破填であり，実験結果とは 対念していないようにみえる。しかし， $V_{c o}$ は $V_{c r}$ の約 1.3 倍であり， せん断ひび割れが十分生じてから壁土が一体となって回転するとは 考えにくく，また， $V_{c o}$ と $V_{s}$ とはほぼ同じ值であることから，この 算定結果は実験結果と大きく異なるものではないと考えられる。ま た, $\mathrm{D} 2 \mathrm{~L} と \mathrm{D} 2 \mathrm{~V}$ 試験体での算定結果はやや過小評価であり, 壁長 が $1820 \mathrm{~mm}$ の試験体では, 中塗り層の厚さに差がある場合の評価に ややばらつきがある。これは, 軸組にせん断変形が生じたとき, 中

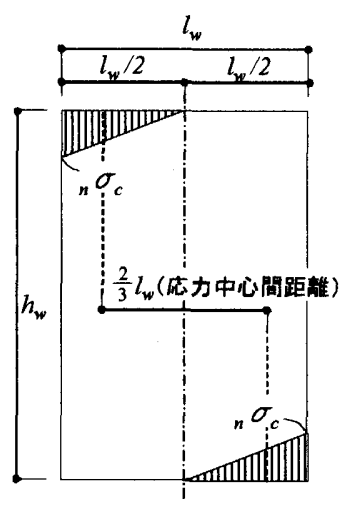

（a）隅角部の応力分布

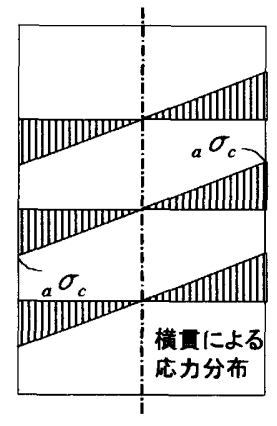

（b）横貫周辺の応力分布
图 17 各部の応力分布の例 
塗り層の剛性が高い場合には，壁土からの大きな反力によって，両 側柱に顕著な曲げ変形が生じ，柱から中塗り層へ作用する応力の分 布が異なるためではないかと考えられる。本実験でも，中塗り層が 厚いほど，ひび割れが対角線方向に集中し（図 7)，柱の水平方向の 変形量が大きい傾向（図 11）がみられている。E2N 試験体では $V_{c o}$ より $V_{c r}$ が小さく, 計算ではせん断ひび割れが発生することになり， 実験においてもせん断ひび割れが確認されている。

本算定式は，この実験結果において必ずしも適切な評価とはなら ない場合もあるが，壁土の破壊形式および中塗り層のせん断耐力は 概ね表現できているといえる。

\section{表 2 中錭り喏の負担せん断カの算定結果}

\begin{tabular}{|c|c|c|c|c|c|c|c|c|}
\hline (単位：kN) & $\mathrm{D} 2$ & $\mathrm{D} 2 \mathrm{~N}$ & D2T & D2L & $\mathrm{D} 2 \mathrm{~V}$ & E2 & E2N & E2T \\
\hline $\begin{array}{c}V_{c r} \\
\text { (ひび割れ登生時) }\end{array}$ & 5.55 & 5. 38 & 9.75 & 2. 52 & 2. 18 & 2. 52 & 2. 37 & 4. 50 \\
\hline $\begin{array}{c}c V_{c o} \\
\text { (隅角部の压填時) }\end{array}$ & 2. 86 & 2.77 & 5.02 & 1. 30 , & 1. 12 & 0.61 & 0.57 & 1.09 \\
\hline $\begin{array}{c}n V_{c o} \\
\text { (貫周辺の圧壤時) }\end{array}$ & 6.54 & 4. 36 & 6.54 & 6.54 & 6.54 & 1. 44 & 1. 92 & 1.44 \\
\hline $\begin{array}{c}V_{s} \\
\text { (조ำ破壊時) }\end{array}$ & 7.64 & 7.41 & 13.43 & 3.47 & 3.01 & (3. 48) & (3. 26) & (6. 19) \\
\hline $\begin{array}{c}V_{c o} \\
\left(={ }_{c} V_{c o}+{ }_{n} V_{c o}\right)\end{array}$ & 9. 39 & $\underline{7.13}$ & 11.55 & 7.83 & 7. 66 & 2.05 & 2.49 & 2.53 \\
\hline $\min \left(V_{s}, V_{c o}\right)$ & 7. 64 & 7.13 & 11.55 & 3.47 & 3.01 & 2. 05 & 2. 49 & 2.53 \\
\hline$V_{\text {exp }}$ & 7. 78 & 7.60 & 10.96 & 4. 38 & 3. 98 & 2.05 & 2. 53 & 2.78 \\
\hline $\begin{array}{l}\text { 実験での } \\
\text { 破畷形式 }\end{array}$ & スリ & プ破填 & 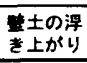 & スリ & プ破晨 & & D漂き & \\
\hline
\end{tabular}

※1 表中の下線は $V_{s}$ と $V_{c o}$ の小さい方の值を示す。 ※2()内の値は参考値として記載した。

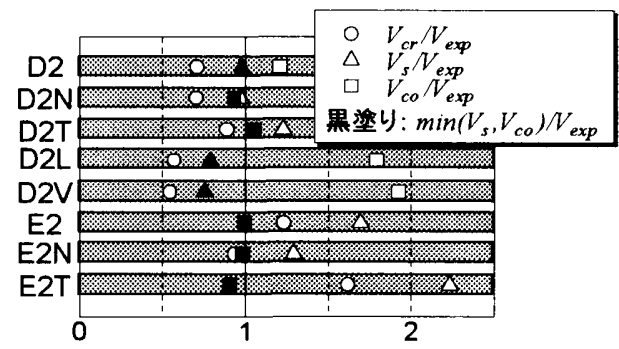

図 18 実験値と計算値との対応

6.まとめ

関東地方でみられる土塗り壁を対象として，中付けおよび中塗り 層の厚さや壁長, 横貫の本数をパラメータとした静的せん断加力試 験を行い，そのせん断抵抗機構について検討した。また，この土塗 り壁のせん断抵抗力の大部分を負担していると考えられる中付けお よび中塗り層について, 壁土の材料試験結果からせん断耐力の算定 を試みた。

算定結果は概数実験值と対応寸るものの，算定に際しての仮定の 妥当性についての検討は十分ではない。中付けおよび中塗り層の厚 さや, 壁土の産地, 軸組や下地の仕様が異なると, 本実験結果と同 様の破壊形式になるとは限らない。今後の検討課題は多いが，土塗 り壁のせん断抵抗機構およびせん断耐力の算定法について，一つの 考え方を示すことができたと考える。

\section{的辞}

本研究は，(財）旭硝子財団の研究助成により行われました。試験 体の製作には，ジェクト（株）の小山良一氏をはじめ，多くの専門 職の皆様にご尽力いただきました。実験の遂行には, 横浜国立大学 大学院生（当時）の嶋豊定氏の協力を得ました。ここに記して感謝 の意を表します。

\section{参考文献}

1）田透平學, 勝田千利, 後藤一雄 : 交番水平荷重を受くる木造有壁骨組（真 壁）の實驗，建築学会大会論文集，pp.130-139，1938.4

2) 久田俊彦:木造壁體の耐力に關する研究, 建築学会諭文集, pp.71-79, 1951.2

3) 杉山英男, 安藤直人: 古文化財に関する保存科学と人文・自然科学 総括 報告書 文化財建造物の構造力学的研究, 1984.3

4）前川秀幸：土塗り壁の静的実験，建策技術，pp.157-161，1997.9

5）鉿木祥之，中治弘行：木造住宅土迬り壁の奏大奏験による耐展性能の再 検討, 日本建策学会構造系論文集, 第 515 号, pp.115-122, 1999.1

6）大橋好光，三芳紀美子：伝統的樓法を用いた木愋構造の設計 土壁，建策 技術, pp.130-133，2003.6

7）村上雅英, 景山諴, 鈴木有, 稲山正弘：静的水平加力赛験に基づく土壁 の耐荷機粠の解明一せん断破壊が先行しない土壁の力学举動一, 日本建 築学会楎造系諭文集，第 582 号, pp.103-108，2004.8

8）中尾方人，山崎裕，田中純：土塗り壁のせん断耐力の評価に関する実験 的研究, 粗造工学詇文集, Vol.49B, pp.573-578, 2003.3

9）一文字里秒，蜡豊定，中尾方人，山崎裕：土塗り壁の耐力および变形性 能の推定に関する実験的研究 (その $21 \mathrm{Px} 3 \mathrm{P}$ の場合)，日本建築学会大 会学術講演梗概集 C-1 樮造 III, pp.397-398, 2003.7

10) 日本建築学会：鉄筇コンクリート構造計算規华・同解説一許容応力度設 計法一，付 11．壁板周辺の柱および梁のせん断破筡を防止または抑制し た霜震壁の楼造計算法, pp.380-404, 1999.11

11）村上雅英，景山誡，岡本滋史，鈴木有，稲山正弘：要素試験による土壁 の水平力耐荷機構の検証一せん断破燷が先行しない土壁の力学举動（続） 一, 日本貄策学会棈造系論文集，第 594号, pp.111-118, 2005.8

讨䎑

壁土の材料試験の供試体は，円筒形の紙管（内径 $50 \mathrm{~mm}$ ，高さ $100 \mathrm{~mm}$ ）を 型枠に用いて製作した。加力は付図のように行い，圧維変位としては，クロ スヘッドの変位を計测した。引張試験の供試体は, 压䌅訊験のものと同じで あり、これに治具を取り付けて引張力を载荷した。

供試体は，概して，圧絠試験では対角線方向にひび割れが生じ，引張試験 では上下の治具間で水平方向に破断した。

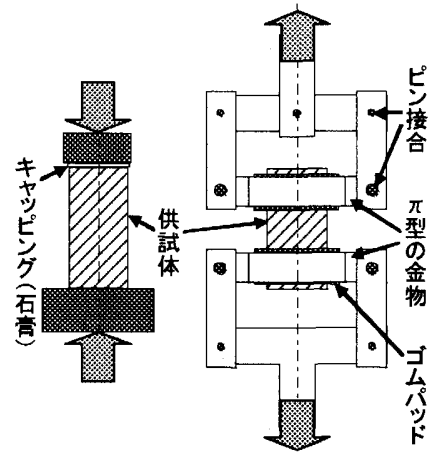

付図 圧縮および引張試験方法

（2005年 4 月 7 日原稿受理， 2005 年 9 月 13 日採用決定） 